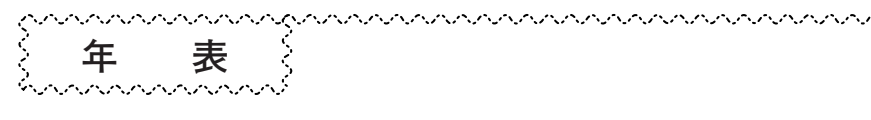

日本表面科学会 29 年の歩み

「表面科学」会誌編集委員会

\section{The Course of the Surface Science Society of Japan from 1979 to 2008}

Hyomen Kagaku Editorial Committee

2008 年 6 月 12 日, 任意団体としての日本表面科学会 は解散し, 社団法人日本表面科学会が新たに設立されま した。社団法人日本表面科学会設立までの歩みと表面科 学の発展を振り返り, 新たな出発を祝したいと思いま す。ここに書かれている出来事は, 現在の編集委員が関 心をもったものであり，重要なものを厳選したわけでは ありませんが，それぞれに時代を映していると思いま す。

1979 年

9 月 13 日 日本表面科学会設立総会を藏前工業会館 で開催。発起人は上田隆三氏，水渡英二氏，清山哲郎 氏。

\section{表面分析の国際標準化が進展。}

1980 年

1 月 1 日 学会事務所を中央科学社内文京区木屋ビル に開室。

6 月 20 日 会誌「表面科学」創刊号を発行。年間 2 冊刊行。内容は, Preface, Overviews, Originals, Current Topics, Conference Reports, Coffee Break, Notice Board。 9 月 12 日 第 1 回表面科学総合講演会を日本化学会 講堂で開催。講演は上田隆三氏, 岡田秀弥氏, 田丸謙 二氏，宮原昭氏，高橋正氏，鎌田仁氏。

12 月末現在 会員数 正会員 1421 名, 名誉会員 3 名, 賛助会員 29 名。

金属単結晶電極を用いた電気化学測定が始まる。 $\mathrm{TiO}_{2}$ の光触媒作用により様々な有機分子を分解でき ることが見出される。

1981 年

3 月 10 日 会誌「表面科学」を本年度より年間 4 冊 発行。Overseas Reports, Laboratory News が加わる。

3 月 14 日 第 1 期通常総会を機械振興会館で開催。

8月 3 6日 第 1 回表面科学セミナーを日本化学会 講堂で開催。講師 13 名による講演と総合討論。
K.M. Siegbahn 氏が高分解能光電子分光法の開発に対 してノーベル物理学賞を受賞。

G. Binnig 氏と H. Rohrer 氏が走査トンネル顕微鏡を 発明。

1982 年

2月 19 20日 第 1 回表面科学討論会を中央大学理 工学部で開催。招待講演 4 件, 一般講演 25 件, 参加 者 200 人弱。

6月 9 11 日 第 1 回表面科学基礎講座「表面分析法 ( I )」を学士会館分館で開催。講師 7 名, 参加者 68 名。

7月 27〜30日 第 2 回表面科学セミナー「セラミッ クス表面・界面の基礎と応用」を日本化学会講堂で開 催。講演 14 件。以後継続し， 2007 年 10 月 10 11 日 に第 28 回セミナーを実施。

10 月 20 日（第 1 回）表面科学シンポジウムを日本 化学会講堂で開催。招待講演のみ 6 件。

10 月 20 日 臨時総会を日本化学会で開催。

会誌へ Technical Notes, Popular Science（第一回目は 「コンタクトレンズ」) が加わる。

フォトンファクトリ完成，1983 年より共同利用開始。 加茂睦和氏らがマイクロ波プラズマ法によりダイヤモ ンドを合成。

外村彰氏が $\mathrm{AB}$ 効果を実験的に観察。

1983 年

2月 9 10 日 第 2 回表面科学討論会を開催。以後, 1985 年 12 月の第 5 回から「表面科学講演大会」に名 称変更して今日に至る。

6月 2 4 日 第 2 回表面科学基礎講座「表面分析法 （II）」を総評会館にて開催。講師 11 名。以後継続し, 2008 年 7 月 2 4 日に第 45 回基礎講座を開催。

Neave 氏, Joyce 氏らが MBE 成長中の RHEED 振動 からステップフロー成長を発見。

G. Binnig 氏と H. Rohrer 氏が STM で Si (111) 7 ×7 再 構成原子構造を観察。

分子科学研究所の UV-SOR が供用開始。

金表面上での有機ジスルフィド分子による自己組織化 膜（SAM）形成が発見される。

1984 年

8 月 1 日 会誌「表面科学」で通常号の他に特集号 「表面物性とセンサ」を発行。年間 5 冊刊行へ。Correspondence, Lecture Note 欄を新設。

小池和幸氏らスピン偏極走査電子顕微鏡を開発。 
1985 年

12 月末, 名誉会員 4 名, 正会員 1155 名, 学生会 員 6 名, 購読会員 37 社, 賛助会員 52 名。 高柳邦夫氏ら Si (111) - (7×7) 表面の DAS モデルを発 表。

Kroto 氏, Smalley 氏, Curl 氏による $\mathrm{C}_{60}$ の発見（こ の 3 人は 1996 年ノーベル化学賞受賞)

G. Binnig 氏と C.F. Quate 氏による原子間力顕微鏡 (AFM) の開発。

表面分析国際標準化を開始。

W. Telieps 氏と E. Bauer 氏が低速電子放射顕微鏡 (LEEM) /光電子放射顕微鏡（PEEM）を開発。

1986 年

6 月 13 日 学会事務局を現在の本郷コーポレーショ ンに移転。

Bednorz 氏と Mueller 氏が酸化物超伝導体を発見。

G. Binnig 氏と H. Rohrer 氏が走査型トンネル顕微鏡 の開発に対して, E. Ruska 氏が電子顕微鏡の開発に 対してノーベル物理学賞を受賞。

1987 年

会誌「表面科学」の記事の区分を日本語とし，巻頭 言, 総説, オリジナル, ノート, 解説, 最近の話題, ポピュラーサイエンス, 研究室紹介, 会議報告, 海外 情報，コーヒーブレイク，用語解説，などとした。表 面科学講演大会論文特集号を刊行。

3 月 1 日 表面分析辞典 (共立出版) を刊行。

Haruta 氏が Au ナノクラスターの高活性を発表。 $90 \mathrm{~K}$ 級酸化物超伝導体の発見。

1988 年

会誌「表面科学」年間 9 冊刊行。

Pashley 氏らが GaAs 表面の STM 観察から As ダイマ 一構造を発見。

1989 年

2 月 10 日 会誌「表面科学」に特集号を加え，年間 10 冊刊行。記事区分は, 巻頭言, 解説, 原著論文, ノート, ポピュラーサイエンス, 談話室, 等とほほ現 行になる。

11 月 29 30 日 日本表面科学会創立 10 周年記念国 際シンポジウム, International Symposium on Surface Science, New Developments and Trends in Surface Science を早稲田大学大隈講堂で開催。

日本表面科学会創立 10 周年記念「表面・薄膜分子設 計シリーズ (共立出版)」を出版。以後, 18 冊刊行。 論文賞を創設。第 1 回受賞者は廣地久美子氏。 板谷謹悟氏が電気化学 STM 装置を用いて水溶液中で Pt (111) 表面構造を観察。
D. Eigler 氏が STM を用いた原子操作に成功。 1990 年

1 月 25 日 第 1 回表面科学研究会「薄膜成長の insitu 観察における最近の成果と展望」を総評会館で開 催。以後継続し，2008 年 3 月 10 日に第 58 回研究会 を開催。

3 月末 名誉会員 3 名, 正会員 1321 名, 学生会員

18 名, 購読会員 54 名, 賛助会員 81 社。

L. Canham 氏がポーラスシリコンの発光を発表。

STM を用いた原子・分子操作が各所から発表される。 1991 年

5 月 17 日 関西支部が発足。事務局は神戸大学，支 部長は金持徹氏。

奨励賞を創設。第 1 回奨励賞は，枝元一之氏。

日本表面科学会創立 10 周年記念として「表面科学の 基礎と応用」を出版。

M. Grätzel 氏と B. O'Regan 氏がグレッチェルセルを 発表。

飯島澄男氏がーボンナノチューブを発見。

北村真一氏らが高温 STM により $\mathrm{Si}$ (111) 表面の再構 成相転移を直接観察。

1992 年

5 月 17 日 中部支部が発足。事務局は名古屋大学,

支部長は一宮彪彦氏。

G. Ertl 氏が日本賞を受賞。

ISO 表面化学分析国際規格が発足。

1993 年

5 月 17 日 東北支部が発足。事務局は東北大学，支 部長は宮本明氏。

1994 年

日本表面科学会創立 15 周年記念として「表面分析図 鑑（共立出版）」を出版。

Lawandy 氏らがランダムレーザー現象を発見。

1995 年

会誌「表面科学」年間 12 冊刊行へ。

5 月 16 日 名誉会員 4 名, 正会員 1246 名, 学生 会員 69 名, 維持会員 10 社, 賛助会員 77 社, 購 読会員 66 社。

技術賞を創設。第 1 回技術賞受賞者は渡部一史氏, 他。

功績賞を創設。第 1 回功績賞受賞者は井上勝也氏, 他。

非接触原子間力顕微鏡の原子分解能が達成される。 $\mathrm{TiO}_{2}$ が光照射により超親水性を発現することが発見 される。

コンビナトリアル合成法の無機材料研究への応用が始 
まる。

1996 年

11 月 25 27日 日本表面科学会創立 15 周年記念国

際シンポジウム, International Symposium on Surface Science, Nano-Control of Environmental Catalysis and Related Materials/Iketani-6 International Symposium on Surface を早稲田大学国際会議場で開催。

2007 年ノーベル化学賞 Ertl 氏らが基調講演。

学会賞を創設。第 1 回受賞者は田中虔一氏と平木昭夫 氏。

1997 年

スチューデント奨励賞を創設。第 1 回受賞者は金田源 太氏，他。

大型放射光施設 SPring-8 が供用開始。

1998 年

11 月 12 13 日 第 1 回薄膜基礎講座を総評会館で開 催。以後継続し，2007 年 9 月 12～13 日に第 10 回薄 膜基礎講座を開催。

表面分析技術選書刊行を開始。「電子プローブ・マイ クロアナライザー」以後, 2008 年までに 9 冊発行。

多探針 STM が開発されナノ物性計測顕微鏡へ発展。 1999 年

11 月 29 日～ 12 月 1 日 創立 20 周年記念事業 International Symposium on Surface Science for Micro-and NanoDevice Fabrication（ISSS-3）を早稲田大学国際会議場 で開催。

フラーレン光重合体の STM による詳細観察や単分子 層薄膜での光重合が観察される。

H.F. Hess 氏らが STM により超伝導磁束を直接観察。 2000 年

5 月 11 日現在 名誉会員 3 名, 功労会員 14 名, 正会員 1183 名, 学生会員 111 名, 維持会員 8 社, 賛助会員 68 社, 購読会員 61 社。

クリントン米国大統領が国家ナノテクノロジー・イニ シアティブ構想を発表。

D. Eigler 氏ら，低温 STM で量子傆気楼現象を発見。 2001 年

3 月 17 日 第 1 回市民講座 (本部主催)「社会を変え るナノサイエンスの世界」を東京大学で開催。

11 月 28 日 第 2 回市民講座「宇宙からの表面科学」 を早稲田大学で開催。毛利衛氏が講演。以後継続し, 2007 年 8 月 11 日には第 8 回市民講座を開催。 2002 年

6 月 24 日 法人化特務委員会が発足。
2003 年

5 月 1 日 e-Journal of Surface Science and Nanotechnology を科学技術振興機構 J-Stage 上で創刊。Editor-inChief は一宮彪彦氏。

4 探針 STM により電子線重合フラーレン薄膜の金属 的伝導特性が発見される。

2004 年

日本表面科学会創立 25 周年記念「新訂版 表面科学 の基礎と応用」を出版。

研究部会制度が発足。

ソフトナノテクノロジー部会と電極表面科学部会が発 足。

講演奨励賞として, 講演奨励賞 (若手研究者部門) 及 び講演奨励賞（スチューデント部門）を創設。

グラフェンが発見される。

2005 年

5 月 10 日現在 名誉会員 14 名, 功労会員 34 名, 正会員 1176 名, 学生会員 163 名, 維持会員 8 社, 賛助会員 61 社, 購読会員 58 社。

11月 14 17 日 創立 25 周年記念国際会議, International Symposium on Surface Science and Nanotechnology （ISSS-4）を大宮ソニックシティで開催。

触媒表面科学部会と放射光表面科学部会が発足。

AFM による新しい原子操作や原子スイッチの開発が 進展。

2006 年

表面科学講演大会を日本真空協会と同一場所・同時期 に開催。また合同セッションを開催。

2 探針 STM によるナノワイヤーの直視と電気伝導計 測が実現。

2007 年

科学技術振興機構 J-STAGEにより会誌「表面科学」 の電子版を刊行開始。

「ナノテクノロジー入門シリーズ」を共立出版から刊 行。

G. Ertl 氏が表面化学における業績に対してノーベル 化学賞を受賞。

2008 年

3 月 31 日現在 名誉会員 19 名, 功労会員 37 名, 正会員 1352 名, 学生会員 251 名, 維持会員 7 社, 賛助会員 65 社, 購読会員 54 社。

5 月 10 日 社団法人日本表面科学会の設立総会を東 京大学にて開催。

6 月 12 日 任意団体としての日本表面科学会を解散。

6 月 12 日 社団法人日本表面科学会を設立。 